\title{
A LECYTHUS FROM ERETRIA WITH THE DEATH OF PRIAM.
}

\author{
[PL. IX.]
}

THE lecythus which is the subject of the present paper, and which is represented, after a drawing by $\mathrm{M}$. Gilliéron, on $\mathrm{Pl}$. IX., was bought by me at Chalcis in December 1893, and is now in the British School at Athens. It is said to come from Eretria, and this statement is doubtless true. Eretria is well known to be a mine of graves of all periods, especially the finest; and many excavations there, both authorized and unauthorized, have enriched the museum of Athens, and, by clandestine export, those of many foreign capitals also. Most conspicuous among the treasures recovered have been the lecythi with paintings upon a white ground. Our lecythus belongs to an uncommon class; a similar, but not identical variety is familiar to readers of the Hellenic Joum nal from the three examples published last year by Miss Sellers. Of the style and technique of the vase I shall speak later; at present we need only notice that the figures are in black or rather a rich dark brown varnish, laid on over a white ground, and that the style of the drawing, which, especially in the profiled outlines of the faces, is much finer than in the lecythi published by Miss Sellers, seems to belong to the beginning of the fifth century-a date which we shall, I think, find consistent with the results derived from more technical evidence.

The vase is of double interest, from its subject as well as its technique. The subject is a remarkable one, and is especially interesting, from a typological point of view, for the light which it throws on the manner in which the Epic tradition is modified by artistic and technical influences. To this the first part of the present paper will be devoted.

\section{I.-SUBJECT.}

In the centre of the field is an altar, with volutes at the top, and raised upon two steps, of which the lower is a high one, the upper a very small one. On this altar sits a bearded man, facing to the left, draped in a himation; his right knee is drawn up, his foot resting on the volute of the altar; he extends both his arms forward as if in supplication to the figure in front of him. Against his knees rest a spear and a shield. From the left there advances towards him another figure in vigorous motion. Unfortunately the upper part of this figure is much damaged; it seems to be that of a young man, clothed in a short chiton, with a breastplate over it, of which the $\pi \tau \tau^{\prime} \rho y \epsilon s$ are visible on the vase. In his right hand he holds, extended at 
arm's length behind him, a severed human head with streaming hair, and he appears to be in the act of hurling it at the bearded man in front of him ; his left arm has entirely disappeared.

Behind the altar stands a woman draped in a himation; she raises her left hand to her head as a token of grief, and stretches out her right in supplication to the young warrior. A staff, spear, or sceptre, which she seems to hold in her right hand, is, I think, meant to be leaning against the altar.

The altar, the young man attacking the old, and the suppliant woman behind, suffice at once to identify the scene. Numerous other representations, differing more or less from the one before us, show in a similar manner the death of Priam at the hand of Neoptolemus, on the altar of his own palace. The woman may, from the type, be either Hecuba or Andromache; the firm and youthful profile seems to point to the latter. The subject is a favourite one among vase-painters of all periods, either as a separate scene, or forming part of a larger composition showing various scenes from the sack of Troy. Professor Robert ${ }^{1}$ has pointed out that the various scenes of the Iliupersis vases were not originally a single composition, from which, in certain cases, various episodes were selected for separate treatment; but that the separate scenes, of more or less independent origin, were later combined into the larger compositions. If we had merely the death of Priam on our vase, our investigation would be a comparatively simple one; it is the complication added by the addition of another element, the barbarous death of Astyanax, whose head we see in the hand of Neoptolemus, that gives to our vase its chief interest.

In its simple form the death of Priam, as we see it represented on vases, conforms usually to one of two main types. The king either lies dead or dying on the altar, while Neoptolemus stands over him, perhaps to give him the coup de grâce, or else he sits or kneels on the altar, and stretches out his arms in supplication to his ruthless enemy. Much more commonly, however, Neoptolemus is represented as holding by one leg the boy Astyanax, whom he swings in the air as if about to hurl him at Priam. Here, too, Priam is sometimes lying dead on the altar, sometimes seated on it; and the same is the case with a third type, represented by our vase and one other, where Neoptolemus is throwing the head only of Astyanax. To put it in a tabular form, we have :

\section{Type $A$.}

(1) Priam lies dead on altar, Neoptolemus stands over him; no Astyanax.-Examples: Gerhard, Auserl. Vasenb. ccxiii.; Röm. Mittheil. 1888, p. 109 ; Furtwängler, Sammlung Sabouroff, 48 ; Brit. Mus. Catalogue, B. 241.

(2) Priam sits on altar, Neoptolemus stands over him; no Astyanax.Example: Röm. Mittheil. 1888, p. 108. 


\section{Type $B$.}

(1) Priam lies dead on altar, Neoptolemus hurls Astyanax by leg.Example: Furtwängler, Sammlung Sabouroff, 49.

(2) Priam sits on altar, Neoptolemus hurls Astyanax by leg.--Examples : Gerhard, Etrusk. und Campan. Vasenbilder 21; Auserl. Vasenb. ccxiv.; Heydemann, Iliupersis i. (Brygos); Arch. Epigr. Mitth. Oest. Ungarn 1893. p. 120 (? Brygos); Arch. Zeitung 1882, p. 39, taf. iii. (Euphronios); Monumenti d. Inst. XI. xiv. ; Brit. Mus. Catalogue, B. 205 ; Berlin Catalogue, 2175.

\section{Type $C$.}

(1) Priam lies dead on altar, Neoptolemus hurls head only of Astyanax.Example: Gerhard, Auserl. Vasenbilder ccxiii.; cf. Arch. Epigr. Mitth. aus Oest. Ungarn ii. p. 29, no. 32.

(2) Priam sits on altar, Neoptolemus hurls head only of Astyanax.Example: our lecythus.

Besides these we have others which show a more or less original treatment of the subject, e.g. the famous Vivenzio vase (Baumeister, taf. xiv, Heydemann, Tliupersis, ii. etc.) where the dead Astyanax lies in the lap of Priam ; but these are the most important for the development of the type.

Let us now proceed to consider the theme as it was originally offered to the vase-painter by Epic tradition, and see how he has adapted and modified it. The story of the fall of Troy, doubtless existing in traditions earlier than any of the set epics that recorded it, formed the subject of the Iliupersis of Arctinus and the Little Iliad of Lesches. According to Arctinus' version, Priam was slain on the altar of Zeus 'E palace; but Astyanax was put to death by a common resolution of the Greeks, chiefly at the instigation of Ulysses; this is the story followed also by Euripides in his Troades. According to Lesches, on the other hand, Priam was dragged by Neoptolemus from the altar, and slain at the door of his house; and Astyanax was hurled by Neoptolemus over the walls of Troy, - a tale evidently known also to the writer of the Iliad itself, to judge from Andromache's prophetic lament (xxiv. 734)

$$
\begin{aligned}
& \text { ทै } \tau \iota \varsigma^{\prime} \mathrm{A} \chi \alpha \iota \hat{\omega} \nu
\end{aligned}
$$

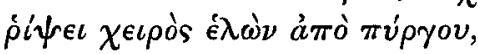

unless indeed the story of the hurling of Astyanax from the walls was originally suggested by this passage. As to the treatment of these, the two most impressive episodes of the sack of Troy, by other writers, such as Stesichorus, we have no clear evidence; but we can see that, while there was a common basis of accepted tradition, there was considerable scope for variety in the details of the story. We know however, of no literary evidence for a tradition of the beheading of Astyanax, as we see it portrayed

2 For others, see Heydemann, Röm. Mitthei7. 1888, p. 104, 105, \&c. 
on two of our vases; nor again is there any literary evidence for a close connexion between these two scenes, so often united on vases. The dramatic effect, if once established in literature, could hardly have failed to leave some trace. The destruction at the same hand and even perhaps by the same blow of Troy's ancient king and the youngest scion of his house, of her link with the past and her hope for the future, forms a most impressive addition to the Iliupersis. But those best acquainted with the methods of Greek vase-painters, and especially with the usual development and adaptation of types in early examples, will hardly be inclined to see here a free invention of the artist for the sake of dramatic effect. Thongh the early vase-painter was always ready to catch at any suggestion offered by technical conditions or accidental juxtaposition, in order to render the scene he was portraying, or to enhance its effect, he rarely if ever ventured on so bold a flight of fancy as would be implied by this combination, if it were a free and original conception. It is far more likely that the suggestion came to him, so to speak, from outside; and I think we may trace the way it came.

The story of the death of Astyanax is very similar to another story also commonly represented on early vases, that of the death of Troilus. In both cases alike it is the youngest and most promising scion of the Trojan royal house that is killed, and killed with circumstances of peculiar barbarity. The murderer is in one case Achilles, in the other case his son Neoptolemus, who replaces him after his death among the Greek leaders. Thus a confusion between the two myths is easy to explain ${ }^{3}$ and that such confusion actually took place among vase-painters seems to me conclusively proved by a comparison between our new lecythus and the representation of the death of Troilus on a vase reproduced in Archaeologische Zeitung xiv. taf. 91. In the two the position of the principal figure, a warrior throwing with his right hand the severed head of a boy, is almost identical; and the presence of the altar in both cases seems to emphasize the identity of the type. In the case of Troilus, the savage cruelty of Achilles, in cutting off the head of his youthful victim, is a regular feature in the representation, and it also has some literary authority. ${ }^{4}$ Beheading was regarded by the Greeks as a peculiarly barbarous form of mutilation, and is quoted, for example, in the the well-known passage at the beginning of the Eumenides ${ }^{5}$ where Apollo mentions various horrors fit for the surroundings of the Furies. In two vases a stage in the story after the death of Troilus is represented; in both his severed head appears. On the vase already quoted ${ }^{6}$ Achilles is brandishing it in his right hand, as if about to throw it in the face of the brothers of his victim, who advance to avenge his death. In the other case ${ }^{7}$ the head appears between the combatants as they advance. Either Achilles

\footnotetext{
3 Cf. Robert, p. 112, where the same fusion is mentioned, only that the Astyanax motive is transferred to Troilus in the vase (Mon. Inst. i. 34).

* Lycophion 313 kaparop $\theta$ eis ; mutilation is
}

mentioned in Sophocles' play, fr. 562 B, Din. dorf. See Areh. Zeitung xiv. p. 230.

5 1. 186.

"Arch. Zeitung xiv. taf. 91.

7 Gerhard, Auserlesene Vaserbilder, ccxx i. 
has already thrown it, and it is flying through the air, or else he has impaled it on the end of his spear, and holds it out to horrify the advancing Trojans; the intention of the artist is not quite clear, but I incline to the first hypothesis, especially as the hair seems to trail behind the head as it flies; the process of the story, too, remains the same, only being represented at a slightly different moment. Now, as there is no trace of a similar story about the mutilation of Astyanax, I think it is quite clear from the two vases with the head of Astyanax, and especially from our lecythus, that this beheading is transferred by the vase-painter from Troilus to Astyanax, and that Achilles' barbarity in the one case is inherited by his son Neoptolemus in the other.

But another feature also appears to have been similarly transferred. According to the story, Achilles slew Troilus at the altar of the Thymbraean Apollo, whither he had pursued him. This altar is most prominent, on all the vases which represent the death of Troilus. ${ }^{8}$ In one case the body of Troilus lies on the altar, just as the body of Priam does in some of the vases representing his death; the body of Astyanax on the Vivenzio vase also lies on the altar, on Priam's knees. When the circumstances of the death of Troilus were transferred, as we see they were, to the death of Astyanax, this altar was transferred also. The altar was particularly convenient where Neoptolemus was represented as hurling Astyanax by one leg; according to the epic version, he hurled him over the walls; but, as Dr. Schneider ${ }^{9}$ very justly observes, a deep abyss is a thing which it is impossible to represent on a vase; and an altar against which he could be dashed forms a fitting substitute. But I do not think it would be a probable substitute, unless some suggestion of the presence of an altar came in from elsewhere, as we see it comes from the death of Troilus. Then the rest follows easily.

We have seen that the Iliupersis as represented on vases is not a varied and original design, but a composition made up of several independent scenes, each having a recognized type of its own. Two of these independent scenes have an altar in them as a most prominent feature ; the death of Priam, which in the epic is connected with an altar; and the death of Astyanax, in which an altar is introduced from confusion with the death of Troilus. In the process of composition, it was natural that these two scenes with an altar should be condensed into one; and thus we have a technical, almost fortuitous origin for a combination which was developed by the vase-painters with full perception of its dramatic force. That the altar is the same in both cases seems to receive farther confirmation from a detail which is not without significance. On the Vivenzio vase and on the Brygos vase ${ }^{10}$ we see a palmtree and a tripod, which do not seem at all appropriate beside the altar of Zeus 'E $\rho$ кîos in Priam's house. But both a palm-tree and a tripod occur, as the appropriate emblems beside an altar of Apollo, in the Troilus scene on

8 For a list of these, see Klein, Euphronios, 2nd. ed. p. $213 s q q$. \&c.
9 Troischer Sagenkreis, p. 172.

10 Heydemann, Iliuporsis 1. 
vases.11 Their reappearance in the Iliupersis scene serves to prove yet more clearly that the altar by which they stand has also been transferred from Troilus to Astyanax.

Thus the juxtaposition of the two scenes, the death of Priam and the death of Astyanax, is explained, and even to some extent their combination into one. But here we enter upon a question which is not so simple as it at first appears. At first sight, one would certainly say that, upon most of the vases which unite the two scenes, Neoptolemus is represented as hurling the boy Astyanax at Priam. But the intention of a Greek vase-painter is not always what is most obvious to the modern eye; and though in the present case I believe the obvious explanation to be the right one, we must not accept it without some consideration. We must remember and allow for the tendency of the Greek artist io get in as much of the story as possible; often what could not, for local or temporal reasons, have been really visible at once. As Professor Robert ${ }^{12}$ puts it, "narration in a sequence of scenes is entirely alien to early art, which condenses all into one scene-but a scene without exact definition of time or space.'

It is interesting to observe the extreme way in which Professor Furtwängler applies this principle to the scene before us..$^{13}$ In the first type, he says, 'Priam, already dead, lies on the altar; Neoptolemus swings Astyanax to hurl him into the abyss; here these two incidents, which according to tradition occurred in two different places, are joined together. In the second type, Priam is still alive; seated or crouching on the altar, he begs mercy of the savage Neoptolemus; the latter grasps Astyanax. Here also two episodes distinct in time are united, for Priam was not pursued and his life threatened at the same time as the child was killed. Yet this composition is just the one chosen and longest kept to ; the great vase-painters Euphronios and Brygos have reproduced it. It is well known that the naive art of early time, instead of avoiding representations like this, condensed so to speak and seeking to group together distinct actions in the same frame, had actually some preference for them. The artists could assume the legend to be well enough known, and so in a case like that which now concerns us they were in no danger of the misunderstanding-into which some modern interpreters have fallen-that Neoptolemus was going to slay Priam by striking him with the body of Astyanax; everybody knew that Neoptolemus was going to hurl the boy from the walls, and afterwards to kill the terrified old man. But art must have had a peculiar delight in uniting these two episodes in the same composition; how could she represent more impressively both the irreparable ruin of Troy and the presumptuous exultation of the conquerors, than by recording at the same time the tragic end of the ancient chief of the people upon the family altar, and that of its last scion, the young Astyanax?'

This extreme view, though based on sound principles, cannot, I think,

\footnotetext{
11 E.g. the Euphronios vase, Gerhard, Auscrl. Vaserb. ccxisiv. \&c.

12 Bild und Leid, p. 17.

13 Samminng Sabouroff, i. 49.
} 
be successfully applied in the case before us. The possibility of a misunderstanding cannot be so easily dismissed, since it has actually occurred in the interpretation of the vases offered by many archaeologists who are familiar enough with the story represented, and who would certainly not have looked for a new and unknown variety of the myth if the known one would have fitted the pictures. In some of the vases Neoptolemus actually grasps Priam by the hair while he swings Astyanax by the leg in his other hand. We surely cannot imagine the vase-painter, however ill-defined the temporal and local conditions may be, to intend here to represent Neoptolemus as hurling the boy over the walls of Troy with one hand, while he grasps Priam with the other. And the presence of the altar of Zeus ${ }^{2}$ E $р \kappa \epsilon i \tilde{o s}$ makes such a feat still more incredible, since it was inside the palace of Priam in the middle of the town; this fact is still farther emphasized on a vase published by Dr. Hartwig, ${ }^{14}$ and attributed by him to Brygos, on which there are visible, behind and above the altar, the remains of a colonnade and architrave which must represent the palace itself.

I think then we may dismiss the theory that the two scenes are only placed in more or less conventional juxtaposition, and not dramatically united. But another point still remains to be decided, though it is rather a matter of detail. Is. Neoptolemus dashing Astyanax against the altar, as a visible and representable substitute for the abyss into which, according to the epic, he hurled the child from the towers of Troy, or is he hurling him as a missile against Priam? Here too our new vase is a help. Whatever be the case with the whole body of Astyanax, we can hardly doubt, that his severed head is used as a missile, just as the head of Troilus is thrown on the two vases we have quoted. It is a piece of wanton cruelty, to add horror to the death of Priam, and so quite in keeping with the other atrocities that marked the terrible night of the sack of Troy: If the head is so thrown at Priam, it seems natural to suppose that the body is also, when we see it swung in the air. In some cases the shut eye seems to indicate that the boy is already dead, so that there was no need to dash his brains out against the altar, though his corpse could be used as a weapon to assail Priam. For all these reasons I think the more forcible and dramatic explanation is also the more probable, and that the vase-painters dereloped to the uttermost the tragic horror of a scene which, in its origin, was due to a technical, almost a fortuitous combination.

One more detail on our vase calls for notice. It has already been observed that a shield and a spear lean against the altar in front of Priam. These cannot, from their position, belong to Neoptolemus, who could not well lean his arms against the knees of his victim just before his impetuous advance against him. They must then belong to Priam. And here our literary illustration must come from a source to

14 Arch. Epigr. Mittheil. aus OesterreichUngarn 1893, p. 123. It must, however, be remembered that here the presence of Astyanax is only a restoration, though a very probable one. 
be used with great caution. In Virgil's wonderful description of the sack of Troy there is a confused and mysterious horror which contrasts strangely with the clear and definite, though often cruel scenes depicted on the Iliupersis vases. The Roman poet is doubtless influenced by the art and literature of later Greece; but there is no reason why he may not have preserved for us some features which belonged to the common inheritance of early tradition; such can only be traced from a coincidence with a representation like that now before us. Aeneas ${ }^{15}$ relates how Priam, when he saw all was lost, armed himself, and was about to rush forth into the fray, until Hecuba persuaded him to lay aside a defence to him so useless, and rather to take refuge at the altar of his palace. It is difficult to see what else can be the meaning of the arms leaning against the altar, but that Priam had thus taken them up and laid them aside on second thoughts; and so this-not the least pathetic-feature of the story gains an authority nearly six centuries earlier than it had before, and at the same time new iight is thrown upon Virgil's use of earlier material. Whether the huge bay-tree which Virgil mentions as growing beside the altar has also any early authority, it is hard to say; but it may very probably have been suggested to the poet by some pictures of the same subject. If so we may very likely seek its origin in the palm-tree which, as we have seen, grew as a symbol beside the altar of the Thymbraean Apollo at which Troilus was slain by Achilles, and which was transplanted, with other elements of the Troilus myth, to the altar in Priam's palace at which Astyanax and the aged king meet a common death by the hand of Neoptolemus.

\section{II.-Style and Technique.}

So far we have been concerned exclusively with the subject represented on our lecythus. Its style and technique are no less worth discussion.

The shape is somewhat ligher and narrower than that of the lecythi published by Miss Sellers; the size rather smaller, the total height being 11 inches $(-275 \mathrm{~m}$.), that of the white ground 5 inches $(125 \mathrm{~m})$; the rim of the mouth is concave on the outside, not bell-shaped; a slight ridge runs round the neck just above the junction with the handle; the foot is almost a frustum of a cone, but with slightly concave sides. The first process in the ornamentation has been the application of the slip to form the white ground, over the upper part of the body only. Then the figures and the rest of the ornamentations have all been added at the same time, and in the same black varnish, thinning out to reddish brown. This varnish forms a plain covering, applied with a brush while the vase was on the wheel, on the upper part of the neck, down to the ridge, on the lower part of the body, the top of the foot, and the lower part of the sides of the foot. It is also applied to the back and sides of the handle, the inside being left bare. 
There is a simple and roughly drawn maeander, bordered by a double line, at the top of the body, on the white ground; and on the shoulder is a double circle of diverging rays, doubtless a simplification of the interlacing lotus-bud pattern.

In the figures, the most remarkable thing is the use of the incised lines, which are not only used freely to represent folds of drapery and other details within the mass of black silhouette, but are also used to define or correct its outlines, especially in the profiles of the faces, which are thus drawn with a firmness of touch and a delicacy and beauty of style which give the chief artistic value to this vase. Other portions, such as the feet of the woman behind Priam, are very carelessly drawn. But the fine profiles can only be paralleled upon the red-figured vases of the Attic masters of about 500 B.c., and this gives us the most trustworthy indication as to date.

Our lecythus must be assigned in the first instance to a somewhat small class, of which it is in some respects, especially in skill of drawing, the most advanced example. This class includes a set of lecythi with black figures on a white ground, representing mythological subjects; almost all the examples that belong to it have been found at Eretria. The style and technique show in all cases a distinct affinity; but the ornamentation, apart from the figures, varies; there is usually some kind of palmette decoration on the shoulder, as on the later white lecythi with outline designs. But this decoration varies in almost all classes, and I doubt whether any hard and fast rule can be made about it. Doubtless it is usually, on outline lecythi, later than the simple ray pattern; ${ }^{16}$ but on the other hand it is impossible, judging by the style, to place our lecythus later than those published in this Journal in 1893. In most cases we find purple used pretty freely on the figures; in one case, the Siren lecythus, white, which, on the whitish ground, is remarkable-to this we shall have to recur.

These Eretrian lecythi, as we are I think justified in calling them from the place where they were mostly found, without as yet drawing any conclusions as to where they were made, form a distinct class among the lecythi with black figures on a white ground. Such lecythi are of course found in great numbers almost wherever Greek vases are discovered; their old name, vases of Locri, is due to their frequency at Locri in South Italy; but it was never a name of any scientific value, and it is now generally given up. The ordinary run of such white lecythi with black figures is almost entirely devoid of artistic or mythological interest, seldom rising above the most common-place shop-work; apart from the Eretrian examples there are very few which repay any detailed study. Many of them may be of later period. They do not therefore afford us much help in an attempt to assign to the Eretrian lecythi their due position in the development of vase-painting.

Other vases with white ground are more important to us. Alabastra are nearest akin to lecythi both in shape and decoration; and alabastra with white ground and black figures upon it form an interesting class-those in

${ }^{16}$ See Mittheil. Athen. 1890, p. 44 (Weisshaüpl). 
particular which have representations of negroes have been often published and discussed. ${ }^{17}$ It would clearly be impossible to speak here of vases with white ground in general. As M. Pottier has pointed out, ${ }^{18}$ there are two rival methods of technique which go back to a very early period in the history of Greek pottery-the one, which gives a hard and smooth surface to the clay of which the vase is made, and then uses it as a ground for decoration; the other, which covers the clay entirely with some pigment, usually white or whitish, and then paints upon this added ground.

All we need notice at present is that there was a very strong growth of this second method in the sixth century, originating, probably, in Rhodes or Asia Minor, and developing to the highest perfection in the fabrics of Cyrene and Naucratis. We shall have to notice later the affinities shown to these two fabrics by the Eretrian lecythi.

There is, however, another class of vases which must first be considered, before we proceed to trace the relations of the different groups. This class, which has been exhaustively treated by M. J. Six in the Gazette Archeologique, ${ }^{19}$ has white or polychrome paintings on a black ground. Thus it also belongs to the second of the two great divisions in method, since in it also the clay of the vase is completely covered by a pigment which serves as a ground for further decoration-the pigment in this case being the ordinary black varnish which is used on black-figured vases to draw the sillhouettes of the figures upon the natural red of the clay, and on red-figured vases to form a background round the figures, which are left open in the same natural red. It is also worthy of note that both varieties of this second method lead to a similar development, whether the added ground is white or black. On the white ground the figure comes to be drawn in outline instead of in silhouette -a process already familiar at Rhodes and Naucratis; on the black ground also we often find outline drawings, but incised not painted, according to the facility offered by the material. ${ }^{20}$

Among these vases with coloured decoration, laid on over a black ground, M. Six distinguishes two classes-or rather one clearly defined class, and beside it a miscellaneous set, which have not very much beyond the technique in common. The more definite class includes a number of bowls with a

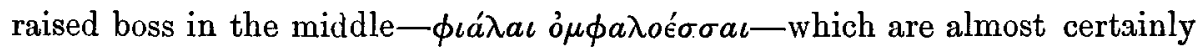
an Athenian imitation of the interior of Naucratite pottery. As to the others, the evidence is not so satisfactory, but some of them are certainly of Attic origin, and there is a strong presumption that all are.

The lecythus with white ground, in its finest form, with outline drawings and polychrome painting, has always been considered an Attic product. ${ }^{21}$ But the finest specimens have been found in great numbers at Eretria ;22 it may

\footnotetext{
17 Froehner, Deux peintures grecques de la Necropole de Kameiros; Heydemann, Arch. Zeitung xxx. p. 35; Winnefeld, Mittheil. Athen. 1889, p. 41 ; ef. also 1890 , p. 243 (Bethe).

18 Bull. Corr. Hell. 1890 , p. 380.
}

\footnotetext{
19 1888, pp. 193 sqq., 281 sqq. Pl. 28, 29.

20 Six., art. cit. p. 198.

${ }_{21}$ Pottier, Les lecythes blancs attiques.

22 See $\Delta \in \lambda \tau$ lav 'A $\rho \chi$. 1888-1892 passim.
} 
indeed be doubted whether those found in or near Athens itself can surpass those that come from Eretria either in quality or quantity. At the same time it is impossible to draw any distinction between the Attic and Eretrian varieties; there are indeed, even apart from the style, indications ${ }^{23}$ which compel us to attribute the outline lecythi found at Eretria to the same hands as not only the Attic lecythi, but even the finest Attic red-figured and outline vases. The only question is whether these Attic lecythi were exported very freely to Eretria, or perhaps more probably some of the Attic potters transferred their workshops to Eretria, where their wares were in so great demand. The enormous number of poor and common-place examples found at Eretria seems to imply a local fabric, of course under Athenian influence.

With the earlier type of Eretrian lecythi to which our example belongsthose representing mythological scenes in black figures upon a white groundthe case is not so simple. The provenance of these lecythi, so far as I know, is almost exclusively Eretria; yet they are customarily spoken of without discussion as Attic. This attribution may be correct; but it certainly is not so obvious as to require no proof. It has been too lightly assumed that, because these earlier lecythi seem to form one series with the later lecythi with outline drawings, of which the Attic affinities are unmistakable, therefore they also were made in Athens. It is not my intention here to decide finally whether the earlier class are Attic or not, but rather to point out that it is a question that has never been discussed, and that the evidence is not so clear as to make discussion superflous.

There is evidence for a close connexion, political as well as artistic, between Eretria and Athens about the beginning of the fifth century. The story that Eretria was originally a colony of Athens, and that there were traces of the original connexion in some early Attic and Eretrian cults, may be apocryphal; but they at least imply some recognized relationship. The Eretrians and Athenians were united in the famous expedition which resulted in the burning of Sardis; and when the Persians retaliated by the invasion under Datis, which ended in the battle of Marathon, Eretria was one of the first objects of their attack, and the Eretrians naturally applied to Athens for help. This help was already on the spot; in the persons of 4000 Athenian settlers, who had been planted sixteen years before in the Chalcidian territory. Under these circumstances, we need not be surprised to find strong affinities with Attic art in the vases buried at Eretria about the beginning of the fifth century. On the other hand we know very little of the art of Eretria at this time. After the total destruction of the city by Datis, and its rebuilding upon a different site, we find a set of vases which cannot in any way be distinguished from Attic.

For the beginning of the fifth century and the end of the sixth, the time to which we must assign the Eretrian vases with black paintings on a white ground, we have hardly any other evidence of a local style of art.

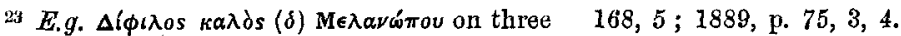
Eretrian lecythi. See $\Delta \in \lambda \tau$ Tov 'ApX. 1888, p.
} 
We must next proceed to notice the affinities which we find in the vases themselves to other early styles, and thus, if possible, to discover their origin and their position in the history of ceramic art.

We have already noticed the essential affinity between vases with black or polychrome figures upon a white ground, and those with white or polychrome figures on a black ground, since in both alike the figures are not laid on directly over the natural clay, but over a slip or varnish intended to conceal it. Both these processes-as it has frequently been observed-became popular in Greece about the same time as the rise of red-figured painting on vases, all three alike resulting from a new artistic impulse and a desire to improve on the old-fashioned black-figured technique. Curiously enough, we know the artist to whom both innovations seem to be due; the name of Nicosthenes appears both upon vases of this period with black figures upon' a white ground, ${ }^{24}$ and also upon a vase which seems a new departure in white figures on a black ground. ${ }^{25}$ The artistic character of Nicosthenes is well enough known, and especially his skill in adapting metal shapes and decorations to pottery; but, although he certainly worked in Athens, his origin is doubtful, and the sources from which he derived his types more doubtful still. $^{26}$ The association of his name does not therefore clear up to any appreciable degree the problems before us.

Without attempting to follow the whole history of vases with a white ground, from Mycenaean to Roman times, we may at least notice the immediate sources from which this technique was introduced into Greece in the sixth century. There can hardly be a doubt that these were the great vase factories of Naucratis and Cyrene. ${ }^{27}$ The character of these two wares is too well known for there to be any need to dwell on it here. What we are now concerned with is the evidence for their influence upon the vases, made in Greece itself, which form the subject of this study. The means by which such influence could be exerted are easy enough to trace. Not only objects which clearly show Egyptian influence, but imports of Egyptian fabric have been found on the Acropolis at Athens; and among these were some characteristic fragments of Naucratite and Cyrenaic pottery. The close friendship of Eretria for Miletus too, which led to the Sardis expedition, would easily lead to commerce with the Milesian colony of Naucratis. The occurrence of the name of Nicosthenes on a vase found at Naucratis is another link; though this vase, like many others, was probably an imported one, most likely from Athens. But the close connexion between the vases of Nicosthenes, with their metallic form and decoration, and those of Cyrene can hardly escape our notice $;^{28}$ indeed, this affinity is so remarkable that one

\footnotetext{
${ }^{24}$ See especially Loeschcke, Arch. Zeitung 1881, 35-38.

${ }_{25}$ Six, Gazette Arch. 1888, p. 192, \&c.

26 For the latest views as to Nicosthenes, see Pottier, Bull. Corr. Hell. 1893, p. 421-444.

27 For Naucratis ware see this Journal, 1887,

Pl, LXXIX., and Naukratis i. and ii. For
}

Cyrene, Puchstein, Arch. Zcitung xxxix. Pl. 10-13. Also Naukratis ii. 50-52 for the difference between the two.

28 See especially the vases published by $\mathbf{M}$. Pottier in the Bull. Corr. Hell. 1892, p. 433444, which show strong Cyrenaic affinities, and also rẹsemble the work of Nicosthencs, 
may be surprised it has not taken a more prominent position hitherto in the discussions of the influences under which Nicosthenes worked. That he imitated foreign models is admitted on all sides, whether those models came, as Professor Loeschcke suggests, from Italy, or, as M. Pottier shows reason for believing, from Ionia. The question of Nicosthenes, however, is too wide a one to discuss here, and would take us too far from our subject: what we need now notice is that the association of his name with the white-ground and black-ground vases is at least not inconsistent with their derivation from the influence of Naucratis and Cyrene.

We now come to more positive and direct evidence. The white ground was the common feature that first led us to the comparison, though its actual composition and the manner in which it is applied differs in the various wares, being doubtless to a great extent due to the local conditions and the available materials. The use, above this ground, of a white pigment -purer white than the ground, which is cream-coloured-is a feature common to Naucratite ware and the lecythus with Odysseus and the Sirens (J.H.S. 1892-3 Pl. I.); and it is in both cases used for the nude parts of female figures; but on the Eretria vase the white is applied over black, and so there is an essential difference of technique, though the result produced in the two cases is similar. The resemblance to Naucratis ware is closer still in some of the late Eretrian vases with outline drawing; closest of all, curiously enough, in those already referred to, which by their Diphilus inscription betray a close connexion with Athens, if not an Athenian origin. Here the white, like the other colours, is laid on directly over the creamy white ground. Another set of vases which we have already noticed as closely akin to the Eretrian lecythi are the alabastra of similar techniqueespecially those with representations of negroes. ${ }^{29}$ There is a close resemblance between these alabastra and Naucratis ware with white ground, especially that variety of it which uses incised lines and chooses grotesque subjects, sometimes negroes. ${ }^{30}$ And if, as Dr. Winnefeld suggests, the alabastra served, somewhat like the Panathenaic vases, to guarantee the quality of their contents, as a precious ointment or scent imported from Egypt, it is most natural that their types should be derived from Naucratis, the Greek colony in Egypt most famous for its vases. ${ }^{31}$

We next come to the influence exercised by the painting in white and red laid on over a black ground which is characteristic of the interior of Naucratite vases. In the first place, a whole series has been found on the Acropolis at Athens of vases which were certainly made in direct imitation of Naucratite ware. A glance at the example figured by M. Six in the Gazette Archéologique 1888, Pl. 28, D, will suffice to prove this to any one familiar with the vases from Naucratis. The decorative development of this

\footnotetext{
29 See above, n. 17, where the references are given. A 4.
}

31 The 'negro' vases are chronologically applicable, since, as Dr. Bethe observes, one has been found in the 'Perserschutt' on the Acro. polis, i.e. was made before $480 \mathrm{B.C}$. 
type in Athens, which is followed out by M. Six, does not here concern us; but the fact is a most interesting one, since a direct imitation implies the probability of less direct influence also. And the imitation occurs in the case of that polychrome painting on the black ground which we have already recognized as technically analogous to painting on white ground. There is, however, another class of polychrome painting on black ground, also treated of by M. Six, which is not confined to decorative designs, and of which the origin is not so certain. Some specimens of this technique were found at Naucratis, but not enough to justify us in assigning it to that town. Sometimes the painting is applied over a black glaze which covers ordinary red Greek pottery (as in the best known example by Nicosthenes); sometimes it is applied to ware which is black throughout. In both cases the analogy to Naucratis ware does not extend beyond the technique, the decorative forms being different, and subjects and human figures being frequent, while they are entirely absent on the inside of Naucratite vases, which alone has this black ground. I have elsewhere ${ }^{32}$ stated my reasons for believing that there is no sufficient reason for believing the black ware with polychrome decoration to have been made at Naucratis itself; but it is doubtless associated with Naucratis, and with those towns in Asia Minor which combined in the colonization of the city. Several examples of the technique have been found in Rhodes, ${ }^{33}$ and the ware is one which is known to have been made in Lesbos. ${ }^{33 a}$ All this fits in excellently with M. Pottier's theory that Nicosthenes derived the models for his vases from Ionia rather than from Italy.

We have, however, wandered rather far from our Eretrian vases, in our attempt to sketch out the influence, direct and indirect, of Naucratis. In the case of Cyrene we can keep closer to the subject. First of all, the technique, with its black figures on a white ground, is almost exactly similar; and the way in which the profile of the faces is outlined with incised lines on our Priam lecythus finds a very close analogy in the Cyrenaic vases figured in Archaeologische Zeitung 1881, taf. 12 and 13. We find also a surprising correspondence of types, which, considering the comparatively small number of examples of each kind which we possess, can hardly be explained as a coincidence. Thus Odysseus, tied to a column instead of the mast of his ship on the Eretrian lecythus J.H.S. xiii. Pl. I., is remarkably similar to the Prometheus, tied to a similar column, on a Cyrenaic vase in Gerhard's Auserlesene Vasenbilder ii. 86; and the hat of Odysseus in the same picture reminds us strongly of the hat worn by Arcesilas on the well-known vase in the Bibliothèque Nationale at Parisdoubtless a sun-helmet such as the African Greeks had found necessary. Again, Heracles on the-Eretrian lecythus J.H.S. xiii., PI. III., is certainly the same type as the Atlas on the same Cyrenaic vase with the Prometheus just mentioned.

The analogy of the very curious treatment of the sea on the Siren

32 J.H.S. 1889, p. $126 . \quad 33$ C. Smith, Naukratis i. p. $49 . \quad$ 33a Naukratis ii. p. 47 ,


lecythus to that on a fragment from the temenos of the Dioscuri at Naucratis has been noticed by Mr. Cecil Smith. ${ }^{34}$ The fragment does not seem to have been made at Naucratis; it resembles no known local ware, and is most probably imported from Ionia. Still we have here one more link of connexion, if not with Naucratis itself, at least with that branch of Greek handicraft with which Naucratis was in commerce. ${ }^{35}$ Many of the analogies here noticed have already been mentioned by Miss Sellers in her publication of the three Eretrian lecythi. The need for a systematic collection and study of vases with a white ground must be felt by all who have had occasion to deal with any of these vases; and until such a collection bas been made, anything written about them must be more or less tentative. But it at least seems clear that both the technique and the types of the lecythi with black figures on a white ground found at Eretria were derived to a great extent from the African colonies of Cyrene and Naucratis, and that they also show affinities with other classes of vases which are probably Ionian in their origin. It remains to be considered whether these conditions are sufficient to determine where the lecythi found at Eretria were made; for we have already seen that the conditions of their discovery do not point clearly to any other place than Eretria as their origin.

The common assumption that all these lecythi were made at Athens seems to rest mainly on the similarity of the later lecythi, with outline drawings, found at Eretria, to those found and doubtless made in Athenswhich, as we have already seen, is not certain: it does not follow that the earlier examples, showing similar shape and decoration, but a different style and technique, were made in Athens also. The facts may easily be explained on another hypothesis. Nor do the influences which we can trace in the earlier lecythi from Eretria seem to me to imply of necessity an Attic origin. Affinities with the wares produced in the African colonies of Cyrene and Naucratis and in Ionia need not surprise us at Eretria. The friendship of Eretria and Miletus was very close and enduring, the Eretrian expedition to Sardis having been undertaken in requital of similar aid given by Miletus to Eretria a hundred years before. And in the case of a city of such commercial activity as Eretria, this friendship would certainly imply close relations with the colonies and allies of Miletus. I think these considerations justify us, at least until further evidence can be produced, in concluding that the class of lecythi of which we have an example before us was made at Eretria, where, so far as I know, examples of this style and technique have exclusively been found. An affinity with Attic art need not surprise us, when we consider the historical relations of Athens and Eretria at the beginning of the fifth century. Later, the lecythus with white ground seems to have been taken up by Attic potters, and to have developed in Athens

34 Quoted by Miss Sellers, J.H.S. 1892-3, p. 3. For the fragment, see Naukratis ii. p. 31, and Brit. Mus. Catalogue of Vases, B. 103, 19 , with illustration.

${ }^{35}$ A similar treatment of the sea may be seen also on the well-known lecythus with the 'keel-hauling', Dumont and Chaplain, Ceramiques de la Grèco propre, Pl. xxiii. (the sea is not shown in the Plate). This is said to have been found in Attica, 


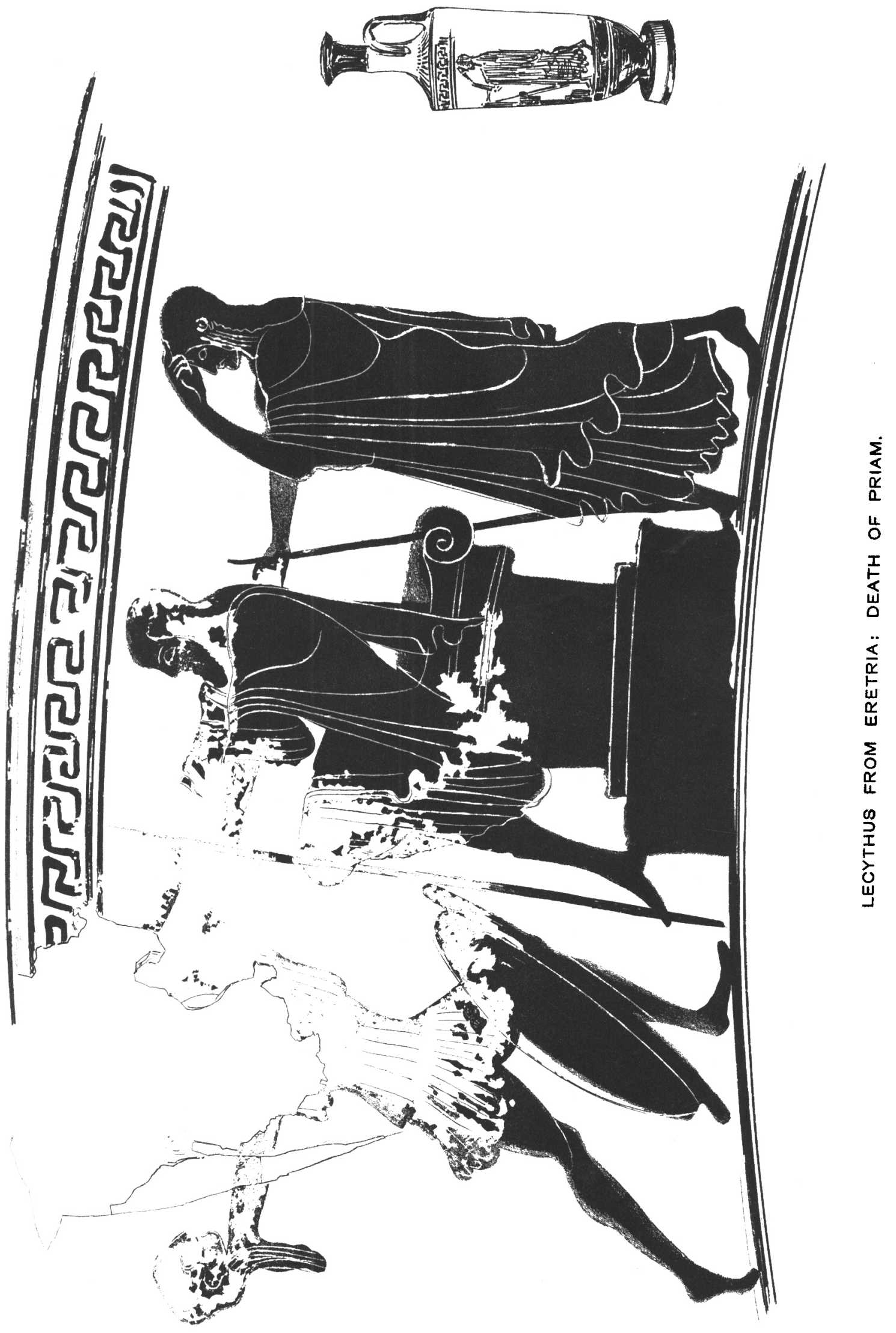


under the same influences which we can trace in the earlier Eretrian examples; and the great series of white lecythi with outline drawings may well have been made both in Athens and Eretria, though always under a predominating Attic influence. But the first development of the lecythus with white ground into something beyond the ordinary 'vases of Locri,' and the recognition of its ultimate possibilities, seem due in the first instance to the potters of Eretria. ${ }^{36}$ The Attic potters, who carried the technique to its highest perfection not only on lecythi but also upon cylices and other vases, may easily spare this credit to a city of which the artistic attainments have hitherto met with scant recognition. There is no adequate reason why Eretrian provenance should be assumed to imply an Attic origin.

\section{E. A. Gardner.}

Note. - I add a brief description of another lecythus of very similar character, which tends to confirm the view expressed above as to an Eretrian fabric.

Lecythus with black figures on white ground-probably from Eretria-in private possession.

Total height $8 \frac{1}{2}$ in. $(22 \mathrm{~m})$; height of white ground $3 \frac{1}{2}$ in. $(\cdot 09 \mathrm{~m})$.

Decoration and shape exactly as Priam lecythus.

Srbiject.-Heracles clad in lion's skin, advancing to right, club in right hand, with left (very roughly drawn) seizes by the throat a kneeling Amazon, armed with shield and spear and high-crested helmet (Hippolyta). From right, another Amazon, similarly armed, advances against Heracles; on left, another runs away, but turns her head and strikes back at him with her spear.

Style and technique.-Purple retouching; incised lines freely used, in the case of Hippolyta alone for whole outline of profile, as on Priam lecythus; but half of it is against arm of Heracles, not white ground. Her mouth is wide open; the mouth, open, but not so wide, is incised on the other profiles. The drawing is vigorous and generally shows a tolerably free and advanced style, but is in places very careless; e.g. Heracles' left arm and hand are a mere shapeless bar of black. There are two conventional branches in the background behind the central group. The figures go all round the body of the vase. The white ground is smoother and less creamy than in the Priam lecythus.

There can hardly be a doubt that this comes out of the same workshop as the Priam lecythus, though it is very inferior in execution.

\section{E. A. Gardner.}

\footnotetext{
${ }^{36}$ Dr. Waldstein suggests to me that the pigment used for the Eretrian white lecythi was the same as the Eretrian earth mentioned by Pliny, xxxv. 38. He tells me this passage sug-
}

gested to him a fabric of vase with white ground at Eretria before his excavations there led him to the same conclusion. 